\title{
Charophyte occurrence in Ceratophyllum demersum stands
}

\author{
M. Pełechaty $\cdot$ E. Pronin $\cdot$ A. Pukacz
}

Received: 27 November 2012/ Accepted: 20 July 2013/Published online: 2 August 2013

(C) The Author(s) 2013. This article is published with open access at Springerlink.com

\begin{abstract}
The hornwort Ceratophyllum demersum is a loosely attached to the bottom or free-floating vascular macrophyte, which builds dense stands in nutrient-rich waters. The hornwort stands are usually monospecific communities with a negligible contribution of other aquatic plants. However, some published literature data and our own observations evidenced the co-occurrence of densely growing Ceratophyllum and other macrophytes, including charophytes, which by contrast to hornwort are indicative of clear and less productive waters. Thus, the aim of this study was to identify the charophyte species growing in $C$. demersum stands and to define the environmental conditions promoting this co-occurrence. In 18 natural lakes of Western Poland, 60 stands of Ceratophyllum
\end{abstract}

Guest editors: M. T. Ferreira, M. O’Hare, K. Szoszkiewicz \& S. Hellsten / Plants in Hydrosystems: From Functional Ecology to Weed Research

\section{Pełechaty $(\bowtie) \cdot$ E. Pronin}

Department of Hydrobiology, Faculty of Biology, Adam Mickiewicz University, Umultowska 89, 61-614 Poznań, Poland

e-mail: marpelhydro@poczta.onet.pl; gubu@o2.pl

\section{A. Pukacz}

Collegium Polonicum, Adam Mickiewicz University in Poznań - European University Viadrina in Frankfurt,

Oder, Kościuszki 1, 69-100 Słubice, Poland

e-mail: andrzejpukacz@wp.pl demersum were studied in the years 2001-2005. A total of 25 species built the studied stands. As many as eight charophyte species, 13 vascular plants, two moss species and one filamentous alga co-occurred with $C$. demersum. Among charophytes rare to Poland Chara polyacantha and Nitella gracilis were identified. Nitellopsis obtusa and Chara globularis revealed the highest frequencies along with Myriophyllum spicatum. Morphology of lakes combined with water quality, particularly transparency, appeared to regulate the coexistence of charophytes and $C$. demersum, macrophytes usually competing with each other.

Keywords Ceratophyllum demersum.

Nitellopsis obtusa . Chara globularis .

Charophytes · Environmental conditions ·

Species co-occurrence

\section{Introduction}

Charophytes (Characeae), macroscopic green algae, are widely distributed in the world, mainly in different types of freshwater habitats. Although, many species are considered rare and some of them are even close to extinction. Thus, for an appropriate management of aquatic ecosystems and protection of rare and endangered species, it seems important to recognize environmental conditions under which charophytes can occur. According to literature, charophytes can 
occupy two different habitat types in freshwaters (Casanova \& Brock, 1999) where they are exposed to varied environmental pressure and play different roles (as summarized in van den Berg et al., 1998; van den Berg, 1999; Kufel \& Kufel, 2002; van Donk \& van de Bund, 2002; Martin et al., 2003; Apolinarska et al., 2011; Pełechaty et al., 2013).

The first habitats are the deepest regions in lakes, where charophytes have a better chance to grow, because they have shade tolerance and abilities to utilize light effectively, which give them better photosynthetic performance as compared to higher plants. The second habitats are shallow aquatic environments, e.g., shallow lakes, ponds, artificial water bodies, wetlands, oxbow lakes, where charophytes are often observed among vascular plants, which grow at the bottom. As shallow waters are frequently eutrophic and more turbid compared to deep ones, angiosperms, particularly canopy forming species, can outcompete charophytes via shading.

Another aquatic macrophyte to occupy similar ecological environments is Ceratophyllum demersum L. This species can inhabit shallow as well as deep littoral habitats (e.g., Tomaszewicz \& Kłosowski, 1990; Pełechata \& Pełechaty, 2010, and references therein) and, comparably to charophytes, it can inhabit low light environments (Mjelde \& Faafeng, 1997, and references therein). Contrary to most charophytes, $C$. demersum is a strong competitor in more fertile waters and can dominate in eutrophic and turbid habitats (Hutchinson, 1975).

Based on the above-cited literature and own field observations performed during the study of macrophyte vegetation of lakes of western Poland (Pukacz et al., 2005; Pełechaty et al., 2007, 2009; Pełechaty \& Pukacz, 2008) we hypothesize that charophytes have abilities to tolerate wide spectrum of lakes conditions under which these macroalgae can co-occur with different macrophyte species, including abundantly developed species specific for higher trophy, such as C. demersum. As a key factor should be given light availability, particularly important for charophytes, but also for other submerged plants. This pattern of charophyte occurrence can be species-specific. Therefore, this study aims were: (i) to identify the charophyte species growing in $C$. demersum stands and (ii) to define lakes properties and stands characteristics promoting the charophyte co-occurrence with $C$. demersum.

\section{Study area and methods}

The study region (Lubuskie Voivodeship, western Poland) is characterized as rich in clear-water lakes of different trophy and mictic types with varied and abundant vascular and charophyte vegetation (Dąmbska, 1961, 1964; Pełechaty et al., 2007; Pełechaty \& Pukacz, 2008; Kraska, 2009). Data for the present paper were collected during the field studies carried out in the vegetation seasons 2001-2005. Different lakes were studied in each year. After a pilot study that allowed to select $C$. demersum stands for further studies, lakes and selected stands were visited once. Altogether 18 natural lakes located mostly in Pojezierze Lubuskie Lake District (Fig. 1) were surveyed. The lakes represent different trophic states, morphometry, mixing regimes, including the rarely observed meromictic lake type, and different character of flow (Table 1).

Representative patches (stands) of Ceratophyllum demersum-dominated community (Ceratophylletum demersi Hild 1956 in terms of phytosociology) were

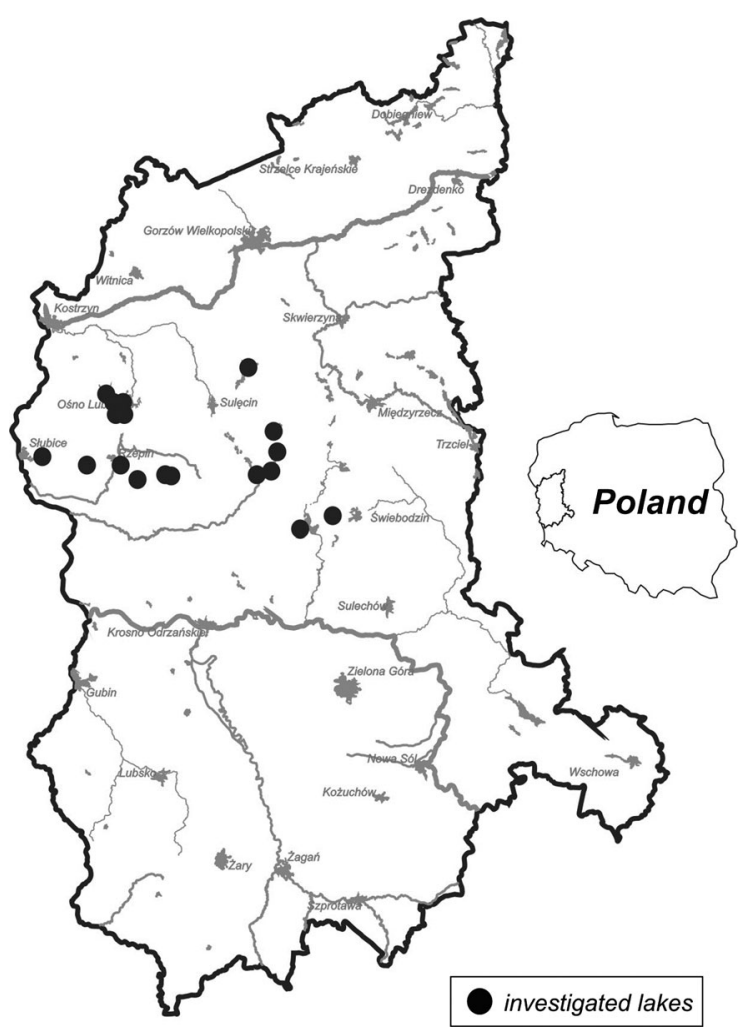

Fig. 1 Spatial distribution of lakes, in which Ceratophyllum demersum stands were investigated 
Table 1 Selected habitat characteristics of investigated lakes
$P$ polymictic, $D$ dimictic, $M$ meromictic, $F$ flow, $O$ outflow, $N$ no flows, $M$ mesotrophic, $E$ eutrophic

\begin{tabular}{lcclll}
\hline Lake & Area (ha) & $\begin{array}{l}\text { Maximum } \\
\text { depth }(\mathrm{m})\end{array}$ & $\begin{array}{l}\text { Mixing } \\
\text { regime }\end{array}$ & $\begin{array}{l}\text { Character } \\
\text { of flow }\end{array}$ & $\begin{array}{l}\text { Trophic } \\
\text { status }\end{array}$ \\
\hline Bielawa & 2.2 & 2.3 & $\mathrm{P}$ & $\mathrm{N}$ & $\mathrm{E}$ \\
Błędno & 4.2 & 2.8 & $\mathrm{P}$ & $\mathrm{N}$ & $\mathrm{E}$ \\
Buszenko & 27.9 & 20 & $\mathrm{D}$ & $\mathrm{O}$ & $\mathrm{M}$ \\
Czyste Wielkie & 26.4 & 20.8 & $\mathrm{D}$ & $\mathrm{N}$ & $\mathrm{M}$ \\
Długie & 6 & 3.2 & $\mathrm{P}$ & $\mathrm{N}$ & $\mathrm{E}$ \\
Grzybno & 42.7 & 13.9 & $\mathrm{D}$ & $\mathrm{O}$ & $\mathrm{M}$ \\
Kocioł & 5.1 & 3.5 & $\mathrm{P}$ & $\mathrm{F}$ & $\mathrm{E}$ \\
Kręcko & 46.5 & 6.9 & $\mathrm{P}$ & $\mathrm{C}$ & $\mathrm{E}$ \\
Linie & 2.1 & 2.3 & $\mathrm{P}$ & $\mathrm{F}$ & $\mathrm{E}$ \\
Lubiąż & 130 & 12.8 & $\mathrm{D}$ & $\mathrm{F}$ & $\mathrm{E}$ \\
Lubińskie & 22.7 & 21.6 & $\mathrm{M}$ & $\mathrm{O}$ & $\mathrm{M}$ \\
Eagowskie & 82.4 & 13.5 & $\mathrm{D}$ & $\mathrm{F}$ & $\mathrm{M}$ \\
Reczynek & 28.2 & 14.8 & $\mathrm{D}$ & $\mathrm{N}$ & $\mathrm{E}$ \\
Trześniowskie & 185.7 & 58.8 & $\mathrm{D}$ & $\mathrm{N}$ & $\mathrm{M}$ \\
Wielicko & 35.1 & 20.7 & $\mathrm{D}$ & $\mathrm{N}$ & $\mathrm{M}$ \\
Wilkowskie & 130.5 & 23.7 & $\mathrm{D}$ & $\mathrm{N}$ & $\mathrm{M}$ \\
Wyspa & 19.3 & 6.6 & $\mathrm{P}$ & $\mathrm{N}$ & $\mathrm{M}$ \\
Złoty Potok & 32.8 & 13.7 & $\mathrm{D}$ & $\mathrm{N}$ & $\mathrm{M}$ \\
\hline
\end{tabular}

of patch, organic matter content in substratum (range from 1 for mineral to 4 for organic substratum, 2 and 3 were assigned to mineral-organic and organicmineral substrata, respectively) and the total plant cover were estimated in the field. Bottom slope was calculated based on the minimum and maximum stand depths and the distance between them.

Macrophytes and charophytes were collected by diving (mainly) or from a boat, using a small anchor with a calibrated rope. Specimens of charophytes were identified according to Dąmbska's (1964) and Krause's (1997) identification keys. An Olympus SZX 9 stereo microscope was used during this work.

In addition to the vegetation study basic physical and chemical water properties (visibility by Secchi disk, $\mathrm{pH}$, conductivity, temperature, and oxygen concentration) were analyzed in situ, in the central, deepest part of each studied lake. The temperature, oxygen concentration, conductivity, and $\mathrm{pH}$ were measured using the portable apparatus Elmetron CX742. Pelagic samples were also collected for further hydrochemical analyses. Nutrient forms, calcium and magnesium concentrations, alkalinity, and total hardness were determined under laboratory conditions according to Standard Methods (Greenberg et al., 1992). 
Study results were elaborated statistically with the use of Statistica 10 (cluster analysis and MannWhitney and Kruskal-Wallis tests) and CANOCO 4.1 (Principal Component Analysis, PCA) softwares. Species composition and structure of the studied $C$. demersum stands were analyzed based on the PCA. The studied stands were divided into two groups based on the presence or absence of charophytes. Then, $C$. demersum stands in which charophytes occurred were analyzed with the use of cluster analysis based on the species composition and coverage, and three groups were distinguished. The significance of differences between the groups was tested with the use of the Mann-Whitney $U$ test and Kruskal-Wallis $H$ test, for two and three distinguished groups, respectively. Physico-chemical and morphological differences between studied lakes were illustrated by the PCA. As nutrients are interrelated, similarly to calcium, magnesium, alkalinity and hardness, the number of properties included in the PCA was limited to those having the highest correlations with the other parameters. Prior to the PCA data were standardized.

\section{Results}

Characteristics of hornwort stands

Apart from C. demersum, a total of 24 species were identified in the studied 60 hornwort stands (Fig. 2) with a maximum number of species per patch reaching nine. On average, three species were noted per patch.

Charophytes were found in 32 phytocoenoses, which constituted $53 \%$ of the studied stands and were represented by as many as eight species. Nitellopsis obtusa (Desvaux) Groves revealed the highest frequency, occurring in 27 patches. In one stand, this species reached up to about $30 \%$ of cover of the stand's area. Chara globularis Thuill. was noted in 13 phytocoenoses, Chara contraria Kütz. in three, Nitella
Fig. 2 Frequency of charophytes, higher plant species and one filamentous alga in 60 Ceratophyllum demersum stands studied in lakes of western Poland

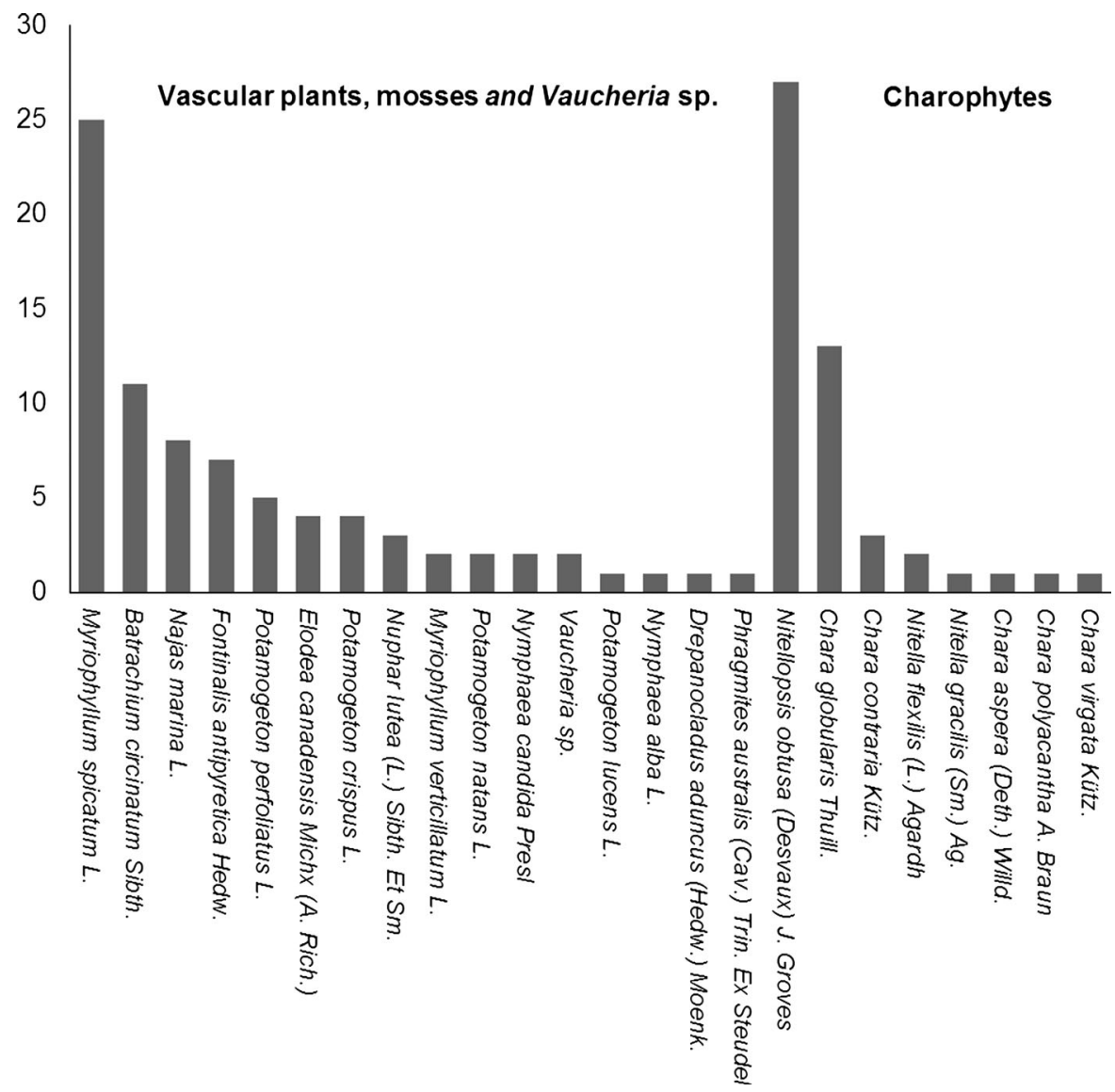


flexilis (L.) Agardh in two, while Chara aspera (Deth.) Willd., Chara delicatula Ag. (syn. Chara virgata Kütz.), Nitella gracilis (Sm.) Ag., and Chara polyacantha A. Braun. were noted only once. In nine patches two charophytes were noted per hornwort stand. In two patches three charophytes occurred per one patch, and, in one stand, even four charophytes were noted (in all cases Nitellopsis obtusa co-occurred with other charophyte species). More abundant occurrence of charophytes was observed in hornwort stands with smaller contribution of elodeides. In nine cases charophytes co-occurred with Ceratophyllum demersum only.

Among vascular plants, Myriophyllum spicatum L. revealed the highest frequency occurring in 25 stands (Fig. 2). In our study, we also observed two moss species and one filamentous alga Vaucheria sp. (Fig. 2). In all studied stands $C$. demersum revealed the greatest coverage and was the only species in 11 stands.

The result of the PCA analysis performed for both the number of occurrences and the coverage of all noted species (Fig. 3) proved that not only the frequencies reflected in Fig. 2 but also the coverage of Nitellopsis obtusa and Chara globularis among charophytes and Myriophyllum spicatum among other macrophytes are significant for the variance in the composition and structure of the studied C. demersum stands. First and second axes with which the three species were most strongly correlated explained $40 \%$ of the variance observed (Fig. 3).

Considering the importance of the two most frequently noted charophytes we performed a comparative analysis of two groups of hornwort stands: with and without charophytes. The differences in species number, stand depth and bottom slope appeared to be statistically significant ( $U$ test, $P<0.05$, Fig. 4). This result showed that $C$. demersum stands in which charophytes occurred revealed higher species diversity, and bottom slope as well as depth of stands as compared with the group of stands without charophytes. For hornwort stands, in which charophytes occurred, cluster analysis was performed to recognize internal differentiation of species composition and structure in this group of stands. As a result, three different groups were distinguished (Fig. 5).

These three groups of patches were compared regarding habitat characteristics and species cover. In view of Kruscal-Wallis $H$ test significant differences

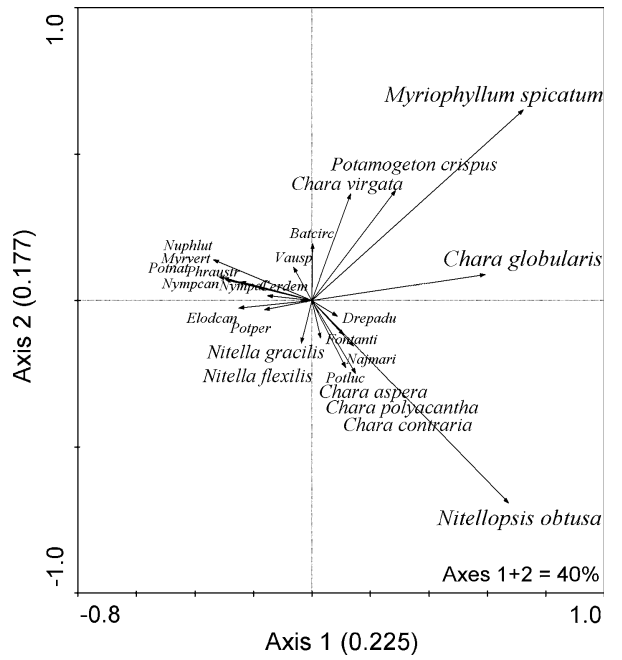

Fig. 3 PCA output for species composition and cover in 60 stands of Ceratophyllum demersum: the significance of Nitellopsis obtusa, Chara globularis and Myriophyllum spicatum contribution in the studied stands. Additionally, less frequent (compare with Fig. 2) but in some stands abundant Potamogeton crispus and Chara virgata as well as other charophytes are displayed. In parentheses eigenvalues are given

in the bottom slope, organic matter content in substratum and cover of the three most frequent macrophytes: Nitellopsis obtusa, Chara globularis, and Myriophyllum spicatum were evidenced (Fig. 6). Differences were also found in $C$. demersum cover but they were not statistically significant among the tested groups of stands. It is worth mentioning that the increase of bottom slope was accompanied by the decrease of organic matter content in substratum (Fig. 6a, b) and coverage of C. demersum (Fig. 6c) as well as Nitellopsis obtusa (Fig. 6e). Moreover, Chara globularis preferred rather mineral and more inclined bottom, where $C$. demersum was less abundant (Fig. 6f). Similar tendency was evidenced for Myriophyllum spicatum (Fig. 6d).

Water properties and morphometry of lakes

In the group of the studied 18 lakes, hornwort stands with the charophyte contribution were found in 13 water bodies. Out of them, 10 are deep stratified lakes, including one meromictic lake. Two further lakes are transitional type between dimictic and polymictic ecosystems, and one was typically polymictic.

Principal components analysis (PCA) was performed in order to find out which physico-chemical 
(a)
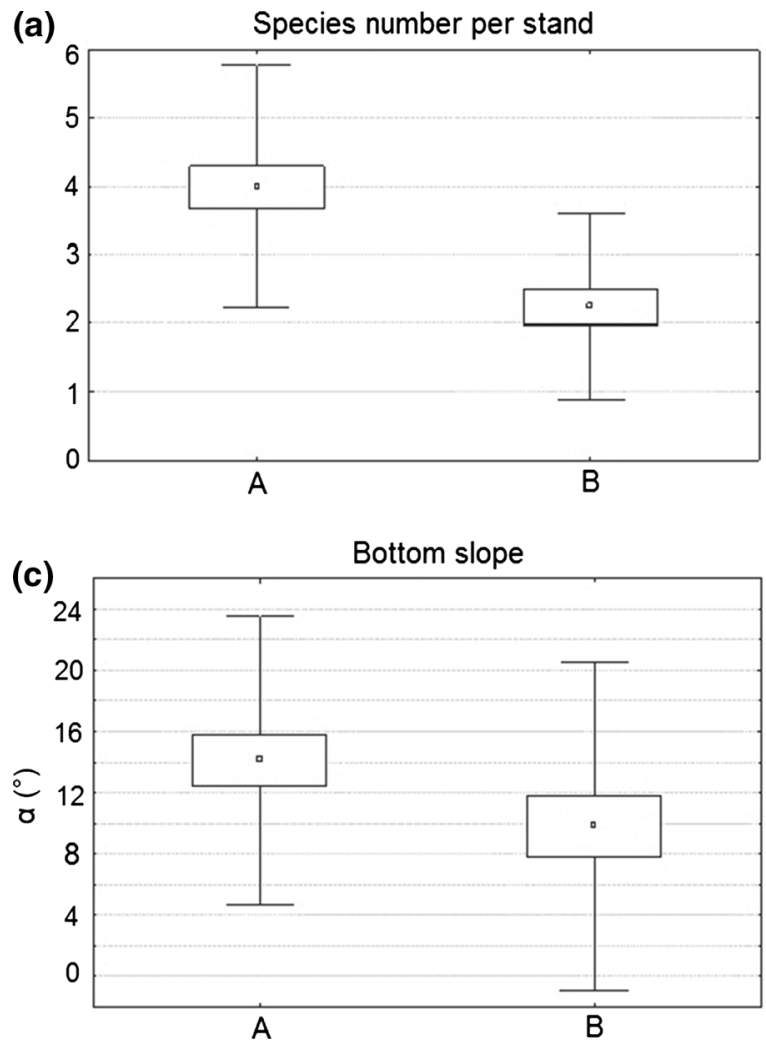

Fig. 4 Differences in species number per stand (a), stand depth (b) and bottom slope (c) between Ceratophyllum demersum stands with $(A, N=32)$ and without $(B, N=28)$ charophytes.

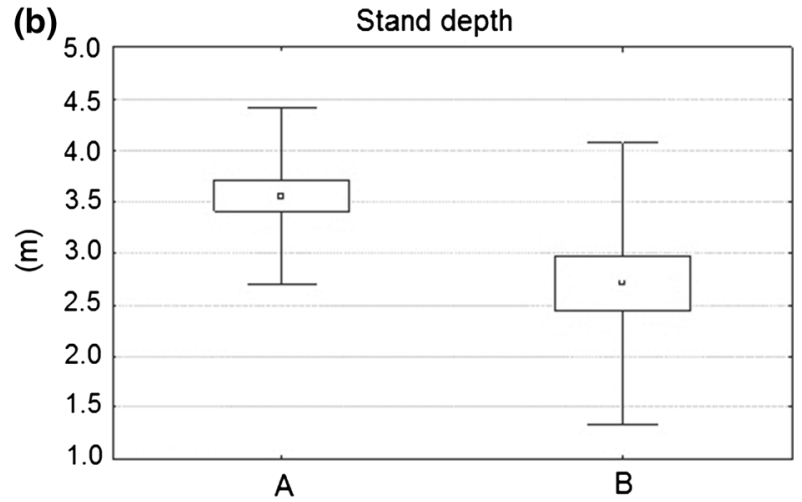

Mean \pm S.E. and S.D. Mann-Whitney $U$ test: $P<0.05$ for all presented characteristics
Fig. 5 Cluster analysis for species composition and coverage of Ceratophyllum demersum stands with charophytes
Ward's metod

Euclidean distance

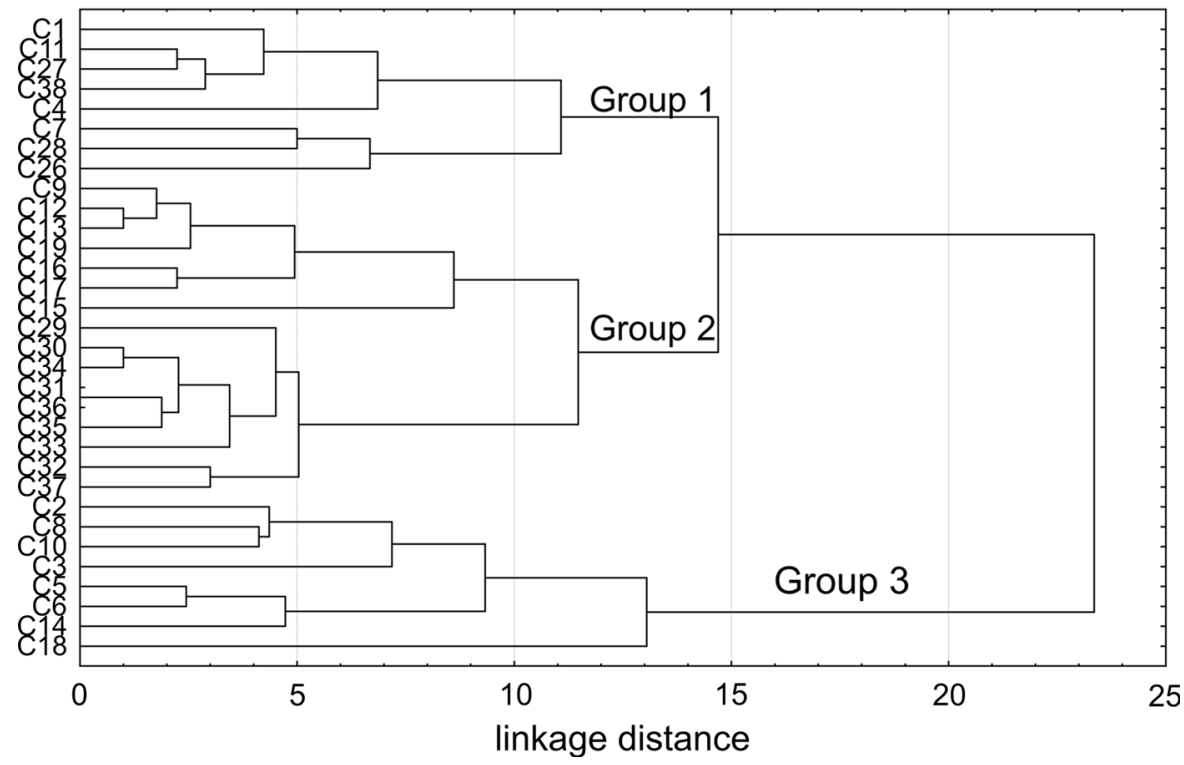


Fig. 6 Basic habitat characteristics and species coverage in three groups of Ceratophyllum demersum stands with charophytes, defined in Fig. 5. a Bottom slope, b organic matter content in substratum, $\mathbf{c} C$. demersum, d Myriophyllum spicatum, e Nitellopsis obtusa, f Chara globularis. Mean \pm S.E. and S.D. Kruskal-Wallis $H$ test: $P<0.05$, except for $C$. demersum. In $\mathbf{c}-\mathbf{f}$, species coverage is expressed in van der Maarel's (1979) scale and in $\mathbf{b}$, organic matter content in substratum is given in four classes of proportion between mineral and organic compounds (both explained in "Study area and methods" section)

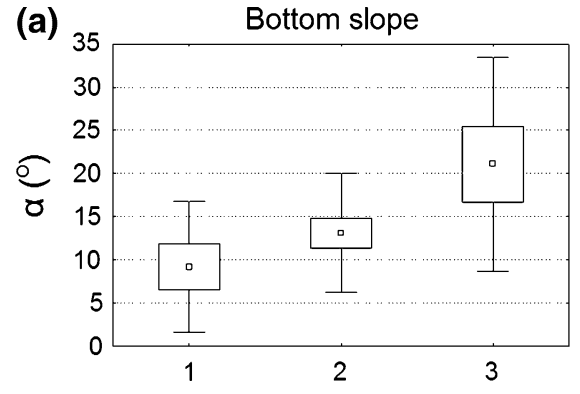

(b) Org. matter content in substratum
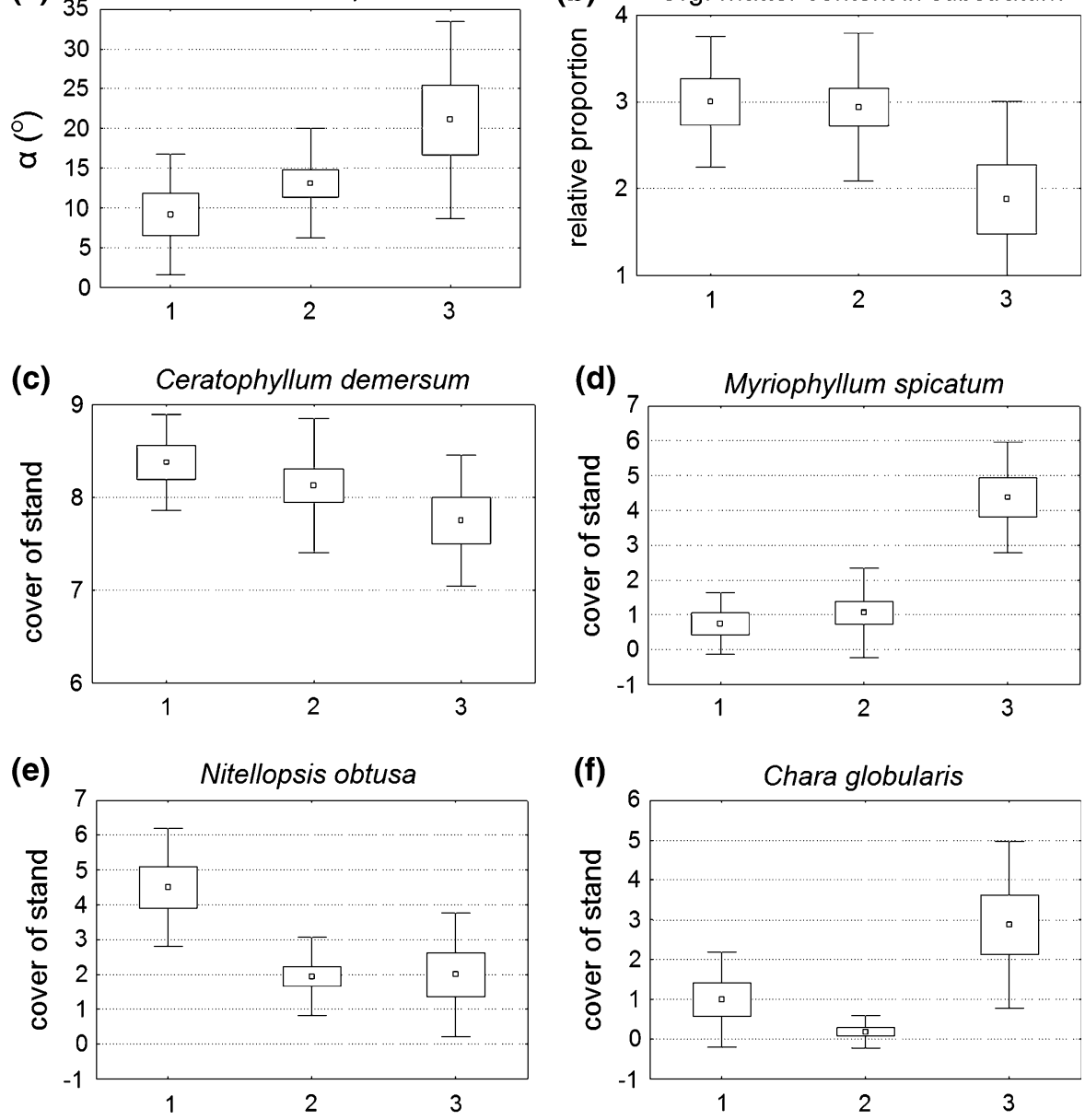

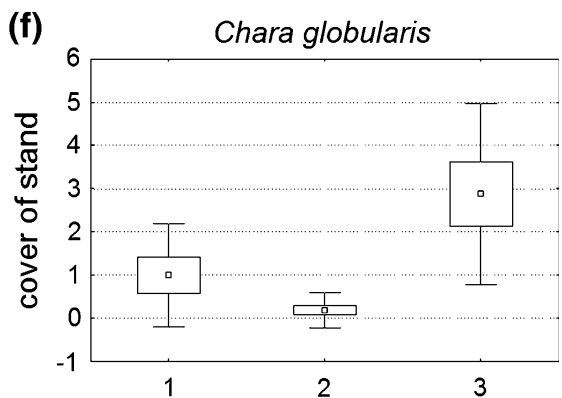

water properties or morphometric features play a key role in differentiation within the group of studied lakes with or without charophyte species in hornwort stands. It was stated that the first and second axes explained about $65 \%$ of variation (Fig. 7). Among physicochemical properties of waters $\mathrm{N}: \mathrm{P}$ ratio, total nitrogen, $\mathrm{Ca}^{2+}, \mathrm{Mg}^{2+}$, conductivity, and temperature showed the strongest relationship with the first main component. Visibility, lakes surface area, $\mathrm{pH}$, and maximum depth were correlated with the second one.

Most lakes without charophytes in Ceratophyllum demersum stands (four out of five) were small and shallow water bodies (Fig. 7). Moreover, three lakes without charophytes in the $C$. demersum stands revealed higher levels of TP and conductivity of water was also higher. On the other hand, lakes with the presence of charophytes in the studied patches of $C$. demersum were bigger and deeper bodies of water as compared to those without charophytes and characterized by better light and oxygen conditions, higher $\mathrm{pH}$, lower total phosphorus concentrations, and higher N:P ratio (Fig. 7).

\section{Discussion}

The study results revealed that in the majority of studied lakes (13 out of 18, Fig. 7) charophytes cooccurred with Ceratophyllum demersum within the stands dominated by this common macrophyte. Available in literature data seem to confirm our findings indicating that charophytes can occur in Ceratophyllum demersum stands when they have favorable growth conditions (Lehmann \& Lachavanne, 1999; Tracy et al., 2003; Mäemets \& Freiberg, 2005; Bazarova \& Itigilova, 2006; Kłosowski, 2006; van de Haterd \& Ter Heerdt, 2007; Kraska, 2009; Pełechaty et al., 2009; Gąbka et al., 2010). 


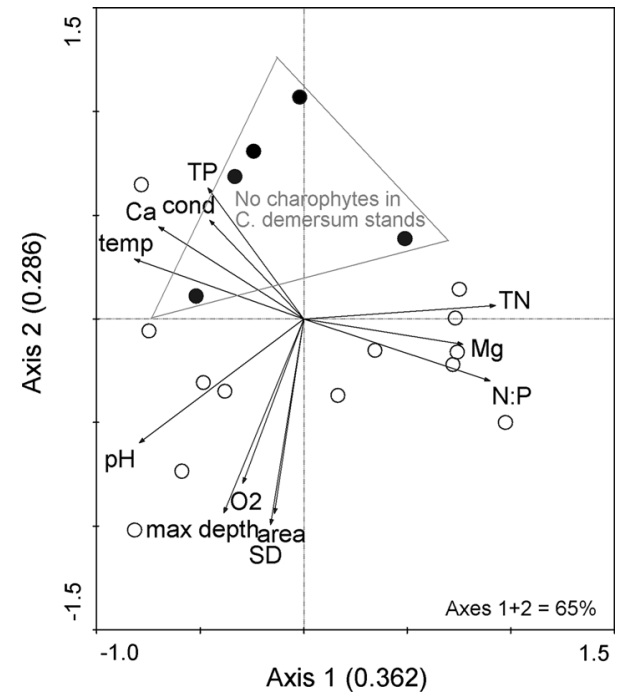

Fig. 7 PCA output for water properties and basic morphometry of 18 studied lakes with Ceratophyllum demersum stands: the differences between lakes with charophytes (white points) and without charophytes (black points) in C. demersum stands. In parentheses eigenvalues are given

In our study, the highest frequencies and coverage were found for Nitellopsis obtusa and Chara globularis (Figs. 2, 3). Both species reveal broad ecological amplitudes and are well-distributed in aquatic environments (Dambska, 1964; Krause, 1997). The two charophytes were evidenced to co-occur with hornwort in lakes of other regions of Poland (Tomaszewicz, 1979). Our study proved that bottom slope and related substratum richness in organic matter seem to be habitat characteristics to promote the occurrence of Nitellopsis obtusa and Chara globularis in $C$. demersum stands (Fig. 6). Published data (Sinkevicièné, 2003; Urbaniak, 2003) provide a variety of accessible water mineralogy, salinity, and sediment types, in which these species can coexist with Ceratophyllum demersum as well as other species such as Myriophyllum spicatum or Vaucheria $c f$ dichotoma, also reported in our study, and the maximum depth limit can depend on competition with the listed species, presumably for light and nutrients. Although the highest frequencies and coverage we found for species of broad ecological spectra, six other charophyte species occurred in the patches dominated by $C$. demersum, including two species considered rare in Poland and protected by the Polish law (Rozp. Ministra Środowiska, Dz. U. poz. 81,
2012): Chara polyacantha and Nitella gracilis. Additionally, according to the Red list of plants and fungi in Poland Chara polyacantha has a status of endangered species (Siemińska et al., 2006).

In the study reported, charophytes occurred in $C$. demersum stands in lakes characterized by better light and oxygen condition and higher $\mathrm{pH}$. In addition, $\mathrm{N}: \mathrm{P}$ ratio was higher in a part of lakes with charophytes present in C. demersum stands (Fig. 7). Greater surface areas and maximum depths of the lakes were also relevant in differentiation between the groups of lakes with and without charophytes in hornwort stands. These findings support the suggestion that features conditioning high water transparency are important for the occurrence of charophytes as light availability promotes high benthic diversity and, thus, coexistence of charophytes with species which are stronger competitors in turbid waters. Under favorable conditions this coexistence is likely to continue for a long period of time, as evidenced by Mäemets \& Freiberg (2005). Along with light availability the significance of N:P ratio seems noteworthy. Growth of non-rooted macrophytes, such as $C$. demersum, is dependent on available nitrogen in the water column (Goulder \& Boatman, 1971; Best, 1980). At least to a certain extent it can be applied to charophytes, too. Species from Characeae family often utilize the nutrients present in water and they only partly use rhizoids anchored in surface layer of sediments for these purposes (Tomaszewicz \& Kłosowski, 1990; Martin et al., 2003). On the other hand, however, high nitrogen loadings are not preferred by diverse benthic vegetation. Tracy et al. (2003) observed an increase of biodiversity in a small and shallow Shoe Lake in southeastern Michigan, USA, after a drought in 1987-1988, during which previously high nitrogen loading decreased in this lake. The authors suggest that the change in nitrogen concentration had a significant influence on the shift from Ceratophyllum-dominated community of low diversity to a more diverse community in next year after drought period. They further suggest that the increase in the overall macrophyte diversity of Shoe Lake was a result of a decline in the dominant non-rooted macrophytes, $C$. demersum and Utricularia vulgaris L., and related increase in light availability for benthic species. Thus, the replacement of abundantly growing $C$. demersum by charophytes is possible. This was the case for one of the lakes in the study reported, where Nitellopsis 
obtusa spread in sites originally occupied by hornwort community and, after 3 years, became a dominant (authors unpublished data).

These above-findings confirm that light availability may have greater influence on the growth of charophyte species in $C$. demersum-dominated patches than nutrient concentration. Pełechaty et al. (2009) evidenced co-occurrence of a rare in the world charophyte species, Lychnothamnus barbatus (Meyen) Leonhardi, with $C$. demersum and postulated that both species can create together a dense mats and increase water transparency by means of a variety of feedbacks described in the theory of alternative stable states (Scheffer et al., 1993). Van den Berg et al. (1998) suggest that charophytes are particularly effective at promoting the clear water state. Since $C$. demersum is also thought to improve water clarity in lakes (Mjelde \& Faafeng, 1997), their coexistence can be expected under favorable light conditions, even thought the competitive exclusion by $C$. demersum is assumed to be one of the reasons for disappearance and quantitative changes in charophytes (Gąbka et al., 2010).

Summarizing the above, we conclude that morphology of lakes combined with water quality create the conditions for coexistence of charophytes and $C$. demersum, macrophytes usually competing with each other. Co-occurring within the same stand, these macrophytes increase together light availability that in turn stabilizes the community the species constitute. This internal community equilibrium seems stable until external influences, mainly understood as human pressure on the lake and related water quality, remain unchanged.

Acknowledgments This study was partly financed by the Polish State Committee for Scientific Research as grant no. 2P04G 113 27. Two anonymous peer-reviewers are kindly acknowledged for valuable comments and suggestions which helped in the manuscript improvements.

Open Access This article is distributed under the terms of the Creative Commons Attribution License which permits any use, distribution, and reproduction in any medium, provided the original author(s) and the source are credited.

\section{References}

Apolinarska, K., M. Pełechaty \& A. Pukacz, 2011. $\mathrm{CaCO}_{3}$ sedimentation by modern charophytes (Characeae): can calcified remains and carbonate $\delta^{13} \mathrm{C}$ and $\delta^{18} \mathrm{O}$ record the ecological state of lakes?: a review. Studia Limnologica et Telmatologica 5(2): 55-66.

Bazarova, B. B. \& M. Ts Itigilova, 2006. Long-term production dynamics of aquatic vegetation in the Arakhlei Lake (Eastern Transbaikalia). Biology Bulletin 33: 68-72.

Best, E. P. H., 1980. Effect of nitrogen on the growth and nitrogen compounds of Ceratophyllum demersum. Aquatic Botany 8: 197-206.

Braun-Blanquet, J., 1964. Pflanzensoziologie, Grundzüge der Vegetationskunde. 3rd edn, Aufl. Springer, Wien.

Casanova, M. \& M. Brock, 1999. Life histories of charophytes from permanent and temporary wetlands in Eastern Australia. Australian Journal of Botany 47: 383-397.

Dąmbska, I., 1961. Roślinne zbiorowiska jeziorne okolic Sierakowa i Międzychodu. [Plant communities of lakes in the surrounding area of Sieraków and Międzychód. In Polish] Poznańskie Towarzystwo Przyjaciół Nauk. Prace Komisji Biologicznej, Poznań 23: 1-120.

Dąmbska, I., 1964. Charophyta: ramienice. [Charophyta: Stoneworts. In Polish]. Państwowe Wydawnictwo Naukowe, Warszawa, Poland.

Gąbka, M., P. M. Owsiany \& L. Burchardt, 2010. The influence of co-occurring vegetation and habitat variables on distribution of rare charophyte species Lychnothamnus barbatus (Meyen) in lakes of western Poland. Polish Journal of Ecology 58: 13-25.

Goulder, R. \& D. J. Boatman, 1971. Evidence that nitrogen supply influences the distribution of a freshwater macrophyte, Ceratophyllum demersum. Journal of Ecology 59: 783-791.

Greenberg, A. E., L. S. Clesceri \& A. D. Eaton, 1992. Standard methods for the examination of water and wastewater, 18th ed. APHA, AWWA, WPCF, Washington, DC.

Hutchinson, G. E., 1975. A treatise on limnology. In Limnological Botany, Vol. 3. Wiley, New York; Chapman and Hall, Ltd., London.

Kłosowski, S., 2006. The relationships between environmental factors and the submerged Potametea associations in lakes of north-eastern Poland. Hydrobiologia 560: 15-29.

Kraska, M., 2009. Roślinność wybranych jezior Pojezierza Lubuskiego i Pojezierza Sławskiego (stan z lat 1977-1981) [Vegetation of selected lakes of Lubuskie Lake District and Sławskie Lake District (state from year 1977-1981). In Polish] Wydawnictwo Naukowe UAM, Poznań: 164-172.

Krause, W., 1997. Charales (Charophyceae). Süsswasserflora von Mitteleuropa, Band 18. Gustav Fischer, Jena.

Kufel, L. \& I. Kufel, 2002. Chara beds acting as nutrient sinks in shallow lakes: a review. Aquatic Botany 72: 249-260.

Lehmann, A. \& J. A. Lachavanne, 1999. Changes in the water quality of Lake Geneva indicated by submerged macrophytes. Freshwater Biology 42: 457-466.

Mäemets, H. \& L. Freiberg, 2005. Long- and short-term changes of the macrophyte vegetation in strongly stratified hypertrophic Lake Verevi. Hydrobiologia 547: 175-184.

Martin, G., K. Torn, I. Blindow, H. Schubert, R. Munsterhjelm \& C. Henricson, 2003. Introduction to charophytes. In Schubert, H. \& I. Blindow (eds), Charophytes of the Baltic Sea. The Baltic Marine Biologists Publications 19, Alfried Krupp von Bohlen und Halbach-Stiftung, Ruggel: 3-14.

Mjelde, M. \& B. A. Faafeng, 1997. Ceratophyllum demersum hampers phytoplankton development in some small Norwegian lakes over a wide range of phosphorus 
concentrations and geographical latitude. Freshwater Biology 37: 355-365.

Pełechata, A. \& M. Pełechaty, 2010. The in situ influence of Ceratophyllum demersum on a phytoplankton assemblage. Oceanological and Hydrobiological Studies 39: 95-101.

Pełechaty, M., A. Pełechata \& A. Pukacz, 2007. Flora i roślinność ramieniowa na tle stanu trofii jezior Pojezierza Lubuskiego (środkowo- zachodnia Polska) [Charophyte flora and vegetation against the background of the trophy state of Lubuskie Lakeland, mid-Western Poland. In Polish]. Uniwersytet im. Adama Mickiewicza w Poznaniu. Bogucki Wydawnictwo Naukowe, Poznań.

Pełechaty, M. \& A. Pukacz, 2008. The state of preservation of charophytes (Characeae) in the waters of the Ziemia Lubuska region (mid-western Poland). Oceanological and Hydrobiological Studies 37: 91-97.

Pełechaty, M., M. Gąbka, P. Sugier, A. Pukacz, S. Chmiel, H. Ciecierska, A. Kolada \& P. M. Owsianny, 2009. Lychnothamnus barbatus in Poland: habitats and associations. Charophytes 2: 13-18.

Pełechaty, M., Pukacz, A., Apolinarska, K., A. Pełechata \& M. Siepak, 2013. The significance of Chara vegetation in the precipitation of lacustrine calcium carbonate. Sedimentology 60(4): 1017-1035. doi:10.1111/sed.12020.

Pukacz, A., M. Pełechaty, A. Pełechata, M. Siepak \& P. Niedzielski, 2005. Phytocoenotic differentiation of Lubuskie Lakeland lakes as related to the habitat properties. Limnological Review 5: 223-229.

Scheffer, M., S. H. Hosper, M.-L. Meijer, B. Moss \& E. Jeppesen, 1993. Alternative equilibria in shallow lakes. Trends in Ecology and Evolution 8(8): 275-279.

Siemińska, J., M. Bąk, J. Dziedzic, M. Gąbka, P. Gregorowicz, T. Mrozińska, M. Pełechaty, P.M. Owsianny, M. Pliński \& A.Witkowski, 2006. Red list of the algae in Poland. In Mirek, Z., K. Zarzycki, W. Wojewoda, Z. Szeląg (eds), Red List of Plants and Fungi in Poland. W. Szafer Institute of Botany, Polish Academy of Sciences, Kraków: 37-52.

Sinkeviciène, Z., 2003. Chara globularis Thuill. 1799. In Schubert, H. \& I. Blindow (eds), Charophytes of the Baltic Sea. The Baltic Marine Biologists Publications 19, Alfried Krupp von Bohlen und Halbach-Stiftung, Ruggel: 99-106.
Rozporządzenie Ministra Środowiska z dnia 5 stycznia 2012 r. w sprawie ochrony gatunkowej roślin [Regulation of the Minister of Environment on the protection of species of plants, January 5, 2012]. Dz. U. poz. 81, Warszawa, January $20,2012$.

Tomaszewicz, H., 1979. Roślinność wodna i szuwarowa Polski. [Aquatic and rush vegetation of Poland. In Polish]. Wydawnictwa Uniwersytetu Warszawskiego, Warszawa.

Tomaszewicz, H. \& T. Kłosowski, 1990. Phytocoenoses of Ceratophylletum demersi Hild 1956 and Charetum tomentosae (Sauer-1937) Corillion 1957 as indicators of habitats of various degrees of eutrophication. Acta Hydrobiologica: 139-154.

Tracy, M., J. M. Montante, T. E. Allenson \& R. A. Hough, 2003. Long-term responses of aquatic macrophyte diversity and community structure to variation in nitrogen loading. Aquatic Botany 77: 43-52.

Urbaniak, J., 2003. Nitellopsis obtusa (Desv. in Loisel.) J. Groves 1919. In Schubert, H. \& I. Blindow (eds), Charophytes of the Baltic Sea. The Baltic Marine Biologists Publications 19, Alfried Krupp von Bohlen und HalbachStiftung, Ruggel: 216-222.

van de Haterd, R. J. W. \& G. N. J. Ter Heerdt, 2007. Potential for the development of submerged macrophytes in eutrophicated shallow peaty lakes after restoration measures. Hydrobiologia 584: 277-290.

van den Berg, M. S., 1999. Charophyte colonization in shallow lakes: processes, ecological aspects and implication for lake managements. Thesis Vrije Universiteit Amsterdam. Drukkerij ve\&es, Deventer.

van den Berg, M. S., M. Scheffer, H. Coops \& J. Simons, 1998. The role of Characean algae in the management of eutrophic shallow lakes. Journal of Phycology 34: 750-756.

van der Maarel, E., 1979. Transformation of cover abundance values in phytosociology and its effects on community similarity. Vegetation 39: 97-114.

van Donk, E. \& W. J. van de Bund, 2002. Impact of submerged macrophytes including charophytes on phyto- and zooplankton communities: allelopathy versus other mechanisms. Aquatic Botany 72: 261-274. 